\title{
Management of Occupational Exposure to Latex: A Nurse with Latex Allergy, Health Problems, Workplace Change
}

\section{Yasemin Yurt ${ }^{*}$ and Meral Turk}

Department of Public Health, Ege Universitesi Tip Fakultesi, Turkey

"Corresponding author: Yurt Y, Department of Public Health, Ege Universitesi Tip Fakultesi, ege univesitesi, tip fakultesi, halk sagligi ana bilim dalı, bornova, Izmır, Turkey, Tel: +902323902065; Fax: +902323880171; E-mail: yurt.yasemin@gmail.com

Received date: May 23, 2017; Accepted date: September 01, 2017; Published date: September 08, 2017

Copyright: ( 2017 Yurt Y, et al. This is an open-access article distributed under the terms of the Creative Commons Attribution License, which permits unrestricted use, distribution, and reproduction in any medium, provided the original author and source are credited

\begin{abstract}
Latex allergy is defined as an allergic reaction to natural rubber proteins. The using of rubber gloves in the health field has increased steadily. Therefore, latex-related allergic reactions have been observed lately. In this case report, we presented clinical findings of a healthcare worker with latex allergy. We emphasized the importance of workplace change in improving the symptoms of the person.
\end{abstract}

A 30 year old male patient has been a nurse intensive care for 6 years. The patient has had rashes, dryness and itching in the workplace for the last 5 years. There was nasal obstruction, increased breathing at work. Dry and ulcerative lesions were observed on the external surface of both hands. Total $\lg E$ was high. Latex specific $\lg E$ was positive. Skin prick test was positive and patch test was positive. The nurse's respiratory function test was assessed normally. The bronchial provocation test was evaluated as positive at $1 \mathrm{mg} / \mathrm{mL}$. Current findings suggest that latex sensitivity and related rhinitis, asthma, urticarial are considered. The medical treatment of the patient was arranged. The workplace change of the kisin was made. He concluded that there is a marked reduction in complaints of shortness of breath, urticaria and rhinitis, which are the result of workplace change.

Latex exposure can be through skin contact and respiration. For exposure precautions, latex-free gloves should be used in persons with contact dermatitis. Latex should not be present in the air where the latex aeroallergens hang in the air to treat symptoms such as allergic rhinitis, conjunctivitis and asthma. For this reason, workplace change must be applied to this person.

In our present situation, workplace changes have been made and a marked improvement in the symptoms of job change outcome has been observed.

Keywords: Latex allergy; Nurse; Occupational disease

\section{Introduction}

Latex allergy is defined as an allergic reaction to natural rubber proteins. The using of rubber gloves in the health field has increased steadily. Therefore, latex-related allergic reactions have been observed lately [1].

In this case report, we presented clinical findings of a health care worker with latex allergy. We emphasized the importance of workplace change in improving the symptoms of the person.

\section{Case}

A 30 year old nurse working in gastroenterology intensive care for 6 years, had contact dermatitis on the hands, nasal obstruction and shortness of breath applied to the occupational health and security unit of the hospital. The nurse's complaints like had dryness, cracking and itching in both hands increased during the last 5 years. The nurse has sneezing, nasal discharge, nasal obstruction, nasal pruritus, throat itching, oculer redness, oculer pruritus for the last 2 years. Three months ago, coughing, wheezing and shortness of breath fort have been added as complaints. The asthma symptoms have been added to present symptoms. The patient was using latex powdered gloves while he was working at the workplace. The patient doesn't smoke nor drink alcohol. He is using montelukast and inhaler formeterol/budezonide. $\mathrm{He}$ is not using any other medication. He does not have any other chronic illness. In his physical examination; his blood pressure was measured $110 / 70 \mathrm{~mm} \mathrm{Hg}$ and his pulse was measured at $61 / \mathrm{min}$. His weight was $63 \mathrm{~kg}$ and his height was $170 \mathrm{~cm}$. His BMI (weight in kilograms divided by the square of height in meters $(\mathrm{m})$ ) was calculated to be $24 \mathrm{~kg} / \mathrm{m}^{2}$. His respiratory voices were normal. He had dryness and ulcerative lesions on the external surface of both hands. The patient was counseled with Immunology-Allergy, Dermatology, Chest Diseases and Otorhinolaryngology. In the laboratory tests; routine biochemistry and hemogram were assessed as normal and Creactive protein (CRP) was negative. Total IgE was $233 \mathrm{IU} / \mathrm{mLT}$ and was assessed high $(\mathrm{H})$. Latex specific IgE RAST was +5 and was assessed positive. Skin Prick Test was +4 and was assessed positive. After the skin prick test, European Standard patch test was done. Only latex positivity was detected in the patch test while the others were negative. İn the test, latex was measured $10 * 8 \mathrm{~mm}$ and as a result latex was evaluated positively. Allergic response to rubber chemicals except latex was negative. FEV1/FVC: 80\%, FEV1: $4250 \mathrm{ml}$ (108\%), FVC: $5030 \mathrm{ml}(114 \%)$ are observed in Pulmonary Function Test (PFT). After PFT, Nonspecific bronchial provocation test was performed with methacholine. There was a 20\% decrease in FEV1. PD20 was $1 \mathrm{mg} / \mathrm{ml}$. The bronchial provocation test was assessed positive. Current findings 
Citation: Yurt Y, Turk M (2017) Management of Occupational Exposure to Latex: A Nurse with Latex Allergy, Health Problems, Workplace Change. J Nurs Care 6: 423. doi:10.4172/2167-1168.1000423

Page 2 of 2

suggest that the patient has latex sensitivity and related rhinitis, asthma, urticaria. Nasal steroid (nasal budesonide) in addition to his current treatment was added to the patient who was diagnosed with allergic rhinitis. The place where the patient was working was changed. Now, the patient is working in the physiotherapy rehabilitation unit and the patient does not use latex powdered gloves. After the workplace has been changed, the patient states that there has been a marked reduction in the complaints of dyspnea, urticaria and rhinitis The patient continues to use his own drugs. The patient continues to go to the allergy-immunology clinic for controlling of disease.

\section{Discussion}

Reactions to latex are widespread in the clinic. Symptoms range widely from irritant contact dermatitis, widespread urticaria, angio edema, allergic rhinitis, asthma and anaphylaxis [2,3].

Among the risk factors identified for the development of latex allergy are occupational groups frequently associated with latex products [4].

For diagnose of latex allergy, history is the most important. It is important that the patient is in a risky group for latex allergy. The patient who has the onset of complaints after contact with latexcontaining products should be examined and diagnosed. It has been shown that skin testing is the most sensitive and unique test method in the diagnostic direction in natural latex allergy. Positive skin prick test in patients suspected of latex allergy diagnosis is strengthened. Skin lesions developed as a type IV hypersensitivity reaction are diagnosed by patch testing [2].
In patients with latex allergy or patients with suspected latex allergy, the basic approach is that patients should be kept away from latexcontaining products and environment with latex [2].

Latex exposure can be directly through skin contact as well as by inhalation. For preventing exposure, non-latex gloves should be used for patients who have contact dermatitis wear regular gloves. Only the patient's glove change may not be useful for treating symptoms such as allergic rhinitis, conjunctivitis and asthma caused by latex aeroallergens hanging in the air. For this, use of latex should not be used in the patient's workplace. Changing of workplace of the patient who has with these symptoms such as allergic rhinitis, conjunctivitis and asthma should be applied if using of latex cannot be avoided in the working environment [5].

In our case, workplace change has been made and as a result the symptoms of the patient have improved significantly.

\section{References}

1. Axelsson JGK, Wragsjö K, Johansson GO (1987) IgE-mediated anaphylactoid reactions to rubber. Allergy 42: 46.

2. Taylor JS, Erkek E (2004) Latexallergy: Diagnosis and management. Dermatol Ther 17: 289-301.

3. Poley GE Jr, Slater JE (2000) Latex allergy: Current reviews of allergy and clinical immunology. J Allergy Clin Immunol 105: 1054-1062.

4. Edlich RF, Woodard CR, Hill LG, Heather CL (2003) Latex allergy: A lifethreatening epidemic for scientists, health care personnel and their patients. J Long Term Eff Med Implants 13: 11-19.

5. Konur O, Canbakan S, Capan N (2006) Latex allergy. Resp Dis 17: 44-54. 